\title{
Normy konferencji episkopatów dotyczące mężczyzn świeckich jako kandydatów do posługi lektoratu i akolitatu
}

\author{
Norms of Episcopal Conferences concerning laymen as candidates for the ministries \\ of lector and acolyte
}

Нормы конференций епископов, касающиеся мужчин-мирян как кандидатов на служение лектората и аколитата

\author{
KS. JERZY ADAMCZYK \\ Dr hab., Katolicki Uniwersytet Lubelski Jana Pawła II \\ e-mail: jerzy.adamczyk@kul.pl, https://orcid.org/0000-0003-1415-7378
}

\begin{abstract}
Streszczenie: Celem artykułu jest ukazanie zagadnienia przepisów konferencji episkopatów dotyczących mężczyzn świeckich jako kandydatów do posługi lektora i akolity. W jego pierwszej części przedstawiono posługę lektora i akolity w Kodeksie prawa kanonicznego z 1983 r. W drugiej ukazano normy komplementarne wybranych konferencji episkopatów odnośnie do wieku i przymiotów kandydatów do posługi lektoratu i akolitatu, natomiast część trzecia została poświęcona innym przepisom konferencji w kwestii kandydatów do posługi lektora i akolity.
\end{abstract}

Słowa kluczowe: posługa, normy komplementarne, lektor, akolita, konferencja episkopatu

Summary: The purpose of the article is to present issues related to the Conference of Episcopates concerning laymen as candidates for the ministries of lector and acolyte. The first part introduces the ministries of lector and acolyte in the Code of Canon Law of 1983. The second part contains complementary norms, selected Conferences of Episcopates according to the age and attributes of candidates for the ministries of lector and acolyte, while the third part is devoted to other provisions of the conference regarding the candidates. The article ends with conclusions and references.

Key words: ministry, complementary norms, lector, acolyte, Episcopal Conference

Резюме: Цель данной статьи - представить вопрос о нормах конференций епископов, касающихся мужчин-мирян как кандидатов на служения: чтеца (лекторат) и прислужника (аколитат). В первой части книги служение лектора и аколита представлено в Кодексе канонического права от 1983 г. Во второй части представлены дополнительные нормы отдельных конференций епископов, касающиеся возраста и качеств кандидатов на служение лектора и аколита, а третья часть посвящена другим правилам конференций, касающимся кандидатов на служение лектора и аколита.

Ключевые слова: служение, дополнительные нормы, лектор, аколит, конференция епископов

\section{Wstęp}

Przez przyjęcie sakramentu chrztu świętego wszyscy wierni uczestniczą w potrójnym posłannictwie Chrystusa: kapłańskim, prorockim i królewskim. Otrzymują 
oni w tym sakramencie charakter sakramentalny, który konsekruje ich do uczestniczenia w chrześcijańskim kulcie religijnym, czyli uzdalnia i włącza chrześcijan do służenia Bogu przez żywy udział w liturgii Kościoła. Konsekwentnie także wierni świeccy mogą wypełniać we wspólnocie przewidziane przez prawo urzędy i posługi. Wśród nich szczególne miejsce zajmują posługa lektoratu i akolitatu. Papież Paweł VI zalecił, aby do tych posług powoływano świeckich mężczyzn żyjących w świecie, a nie tylko kandydatów do sakramentu święceń. Kodeks prawa kanonicznego w kan. $230 \$ 1$ postanawia: „Mężczyźni świeccy, posiadający wiek i przymioty ustalone zarządzeniem Konferencji Episkopatu, mogą być na stałe przyjęci, przepisanym obrzędem liturgicznym, do posługi lektora i akolity, udzielenie jednak tych posług nie daje im prawa do utrzymania czy wynagrodzenia ze strony

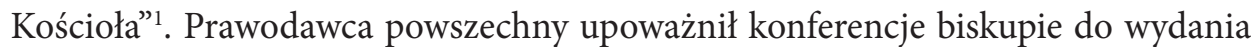
szczegółowych przepisów dotyczących wieku i przymiotów mężczyzn świeckich jako kandydatów do posługi lektoratu i akolitatu.

Powstaje zatem kwestia: jak zadanie postawione przed konferencjami biskupimi przez prawodawcę kodeksowego w zakresie wydania norm dotyczących wieku i przymiotów kandydatów do posługi lektoratu i akolitatu wypełniły określone konferencje episkopatów. Jaki wiek ustalono do podjęcia na stałe posługi lektora i akolity, jakie przymioty i kwalifikacje winni posiadać kandydaci do wspomnianych posług? Czy konferencje episkopatów dostosowały swoje dekrety do miejscowych warunków? Czy wydały też inne normy poza określeniem wieku i przymiotów odnośnie do kandydatów na lektorów i akolitów? Zasygnalizowanym problemom zostanie poświęcony niniejszy artykuł.

\section{Posługa lektora i akolity w Kodeksie prawa kanonicznego z 1983 r.}

Posoborowa reforma święceń wprowadziła w miejsce święceń niższych i święcenia subdiakonatu obowiązkowo dwie posługi: lektoratu i akolitatu². Mają je na okres przejściowy przyjąć kandydaci do kapłaństwa. Motu proprio Minsteria quaedam ${ }^{3}$, a za nim Kodeks prawa kanonicznego z 1983 r. wprowadzają możliwość udzielania posług lektoratu i akolitatu na stałe wiernym świeckim pod warunkami określo-

1 Por. Konferencja Episkopatu Polski, Instrukcja w sprawie udzielania posługi lektora i akolity świeckim mężczyznom (2.10.2007), Anamnesis 2008, nr 52, s. 45.

2 Paulus PP. VI, Motu proprio Ministeria quaedam (15.09.1972), Acta Apostolicae Sedis (dalej: AAS) 64(1972), s. 532-533 (dalej: MQ).

$3 \mathrm{Nr} 3$. 
nymi przez konferencję biskupów. Prawodawca rezerwuje jednak ich udzielenie tylko mężczyznom ${ }^{4}$, zaznaczając, że udzielenie ich nie daje przyjmującym prawa do otrzymania wynagrodzenia ze strony Kościoła, pomimo ich stabilności w posłudze. Prawodawca w kan. $230 \$ 1^{5}$ postanawia: „Mężczyźni świeccy, posiadający wiek i przymioty ustalone zarządzeniem Konferencji Episkopatu, mogą być na stałe przyjęci, przepisanym obrzędem liturgicznym, do posługi lektora i akolity, udzielenie jednak tych posług nie daje im prawa do utrzymania czy wynagrodzenia ze strony Kościoła”. Ustanowieni lektorzy i akolici uzyskują stabilność w swojej posłudze, która wykracza poza pełnienie swojej funkcji podczas celebracji liturgicznych. Dopuszczenie do tych posług musi być zgodne z wytycznymi miejscowej konferencji episkopatu i z reguły będzie obejmowało opracowanie przez tę konferencję rytuału ustanowienia lektorów i akolitów ${ }^{7}$. Kan. $230 \$ 1$ wyraźnie obliguje konferencje episkopatu do określenia wieku i przymiotów kandydatów na stałych lektorów i akolitów ${ }^{8}$.

Wolno sądzić, że zarezerwowanie stałej i oficjalnej (nadanie ministerium oficjalnie, poprzez przepisany obrzęd liturgiczny) posług lektora i akolity z kan. $230 \$ 1$ dla mężczyzn można wyjaśnić tym, że instytucje te, wywodzące się ze sfery duchownej, funkcjonują w kontekście przygotowania do przyjęcia sakramentu święceń, które

4 W obecnym stanie prawnym tylko mężczyźni mogą być na stałe lektorami i akolitami. „Urząd lektora i akolity według czcigodnej tradycji Kościoła jest zastrzeżony mężczyznom, MQ, nr 7. Zob. refleksje na temat możliwości udzielania wspomnianych posług kobietom: D. Barr, Commentary on canon 230, w: New Commentary on the Code of Canon Law, red. J. Beal, New York 2000, s. 299, a także: M. Blanco, La mujer en el ordenamiento jurídico canónico, Ius Ecclesiae 1992, t. 4, nr 2, s. 624-625.

5 Kan. 230 ustanawia trzy rodzaje posług o walorze prawnym, które mogą pełnić świeccy: stałe, które otrzymuje się poprzez obrzęd liturgiczny (oficjalnie), czyli posługi lektoratu i akolitatu, zarezerwowane tylko dla mężczyzn (kan. $230 \$ 1$ ); czasowe, bez instytucji rytualnej i dostępne dla wszystkich świeckich, także kobiet (kan. $230 \$ 2$ ); ministeria nadzwyczajne lub zastępcze w zastępstwie szafarzy wyświęconych lub ustanowionych (kan. $230 \$ 3$ ).

6 Codex Iuris Canonici auctoritate Ioannis Pauli PP. II promulgatus (25.01.1983 r.), AAS 75(1983), pars II, s. 1-317; tekst polski Kodeks Prawa Kanonicznego, przekład polski zatwierdzony przez Konferencje Episkopatu, Poznań 1984 (dalej: KPK); por. J. Dyduch, Komentarz do kan. 230, w: Komentarz do Kodeksu Prawa Kanonicznego, t. 2, ks. II (1). Lud Boży, red. J. Krukowski i in., Poznań 2005, s. 51-53; por. tenże Udział świeckich w kulcie liturgicznym w świetle Kodeksu prawa kanonicznego, Ruch Biblijny i Liturgiczny 1985, nr 1, s. 17. Kan. $230 \$ 1$ jest jedynym w tytule II, cz. I, ks. IV KPK, który wprowadza rozróżnienie między mężczyznami i kobietami. D. Barr, Commentary..., s. 298-301.

7 D. Barr, Commentary ..., s. 299. Pozaliturgiczne funkcje lektora i akolity wylicza MQ w nr 5-6.

8 A. Casaroli (Secretairerie d'Etat), Ai presidenti delle Conferenze Episcopali, Communicationes 1983, t. 15, nr 2, s. 138, nr 1. „Biskup niech wspiera posługę lektorów i akolitów - do której mogą być dopuszczeni mężczyźni świeccy, poprzez odpowiedni obrzęd liturgiczny - uwzględniwszy dyspozycje poszczególnych Konferencji Episkopatu". Congregatio pro Episcopis, Direttorio per il ministero pastorale dei vescovi (22 febbraio 2004), nr 113, Città del Vaticano 2004; tekst polski: Kongregacja do spraw Biskupów, Dyrektorium o pasterskiej posłudze biskupów „Apostolorum Successores”, Kielce 2005 (dalej: AS). 
w Kościele katolickim są zarezerwowane tylko dla mężczyzn, mimo że ci lektorzy i akolici nie przygotowują się do święceń'. W związku z tym Maria Fernández Conde utrzymuje, że „zastrzeżenie to prawdopodobnie przypomina ich dawne [posług lektora i akolity - J.A.] powiązanie z obszarem duchownym. W ten sposób podważa ono zasadę fundamentalnej równości wiernych ustaloną w LG 32, która jest kamieniem węgielnym koncepcji Kościoła-Komunii i Kościoła-Ludu Bożego"10.

Wydaje się, że pojęcie „posługa” w odniesieniu do lektora i akolity jest bardziej odpowiednie niż termin „urząd kościelny”, gdyż w sposób bardziej oczywisty ukazuje, że posługa tych świeckich nie polega na uzupełnianiu niedoboru właściwych szafarzy, ale na wykonywaniu swojej szczególnej formy uczestnictwa w potrójnym posłannictwie Chrystusa ${ }^{11}$.

Ann Jacobs pisze: „Zobowiązani jedynie na mocy chrztu do udziału w ewangelizacyjnej i uświęcającej misji Kościoła niektórzy wierni mogą być dopuszczeni do niektórych posług. Jednak zdolność, jaką wierni otrzymują poprzez swój chrzest i bierzmowanie do pełnienia posług w Kościele, jest niewystarczająca do sprawowania tego obowiązku. Trzeba im go jeszcze powierzyć na mocy specjalnego aktu. Nikt nie przydziela sobie oficjalnej misji; musiał ją otrzymać. Chodzi tu o naturę posługi i Kościoła, o jego chrystologiczny charakter. Panem Kościoła jest bowiem Chrystus zmartwychwstały, w którego imieniu, w Duchu Świętym, dokonuje się misja zbawienia. Osobiste inicjatywy, osobiste świadectwa są z pewnością istotne dla życia Kościoła, ale sytuują się na innym poziomie niż posługi. Instytucja ministeriów jest w służbie tej pełni życia w Chrystusie. Nie każde zadanie jest służbą Kościoła, w sensie kanonicznym, nawet jeśli jest ono bardzo pożyteczne dla Kościoła i stanowi część jego działalności. Kiedy mówimy o posłudze Kościoła, mówimy

9 Por. J. Díaz Moreno, Los laicos en el nuevo Código de Derecho Canónico. Temática actual, Revista Española de Derecho Canónico 1989, t. 46, nr 126, s. 54. To, że tylko mężczyźni mogą być powołani do instytucjonalnych posług lektora i akolity, można wytłumaczyć faktem, że przez wiele wieków posługi te były dwoma święceniami niższymi zarezerwowanymi dla duchownych i że pozostają one również obowiązkowym etapem w drodze do kapłaństwa. A. Jacobs, Les laïcs, membres du peuple de Dieu, à travers le Code de droit canonique, Revue Théologique de Louvain 1987, nr 18, s. 44.

10 M. Fernández Conde, La misión profética de los laicos del Concilio Vaticano II nuestros días. El laico, «signo profético» en los ámbitos de la Iglesia y del mundo, Roma 2001, s. 204. „Z racji odrodzenia w Chrystusie wszyscy wierni są równi co do godności i działania, na skutek czego każdy, zgodnie z własną pozycją i zadaniem współpracuje w budowaniu Ciała Chrystusowego" (kan. 208).

11 Por. M. Fernández Conde, La misión profética..., s. 203-204. Paweł VI dokumenem Ministeria quaedam zniósł „święcenia niższe” i pozostawił dwie „posługi ustanowione” (posługi instytucjonalne) lektora i akolity, aby wspierać wspólnotę chrześcijańską w obszarze słowa Bożego (lektor) i sakramentów (akolita). Te posługi są właściwe dla świeckich: ten, który został dla nich ustanowiony, nie przechodzi do stanu duchownego, ale otrzymuje to oficjalne zadanie w zgodzie ze swoją świecką tożsamością. Por. J. Aldazábal, Vocabulario básico de liturgia, Barcelona 2002, s. 237. 
o oficjalnej misji Kościoła, która jest wykonywana publicznie, o misji budowania Kościoła, o jego działalności podstawowej”' ${ }^{2}$.

Paweł VI znosząc „święcenia niższe”, a jednocześnie udostępniając niektóre z nich (lektorat i akolitat) świeckim, w nowy sposób uwypuklił relację pomiędzy „ministeriami wyświęconych” i „ministeriami ustanowionych” ${ }^{13}$ oraz pomiędzy ich posiadaczami. O ile „ministerium wyświęconych” ma charakter hierarchiczny, o tyle "ministerium ustanowionych” jest przede wszystkim posługą współpracy, współpracy z ministrami wyświęconymi ${ }^{14}$. Fakt, że minister jest „ustanowiony” (a nie „wyświęcony”) przez obrzęd liturgiczny, nie przyznaje mu ani żadnej władzy, ani praw właściwych dla sakramentu święceń, a jedynie obowiązek wykonywania swojej posługi w sposób stabilny w Kościele. Jednak nie można przeoczyć faktu, że z chwilą powierzenia przez ordynariusza poprzez obrzęd liturgiczny posługi lektoratu czy akolitatu ich tytulariusze zostają wyposażeni w pewien autorytet w odniesieniu do wspólnoty w obszarze pełnionej przez nich funkcji, ponieważ wspomniany obrzęd liturgiczny powierzenia tych posług legalizuje ich działanie w imieniu Kościoła ${ }^{15}$.

Posługi lektora i akolity muszą być wykonywane w sposób stabilny (jest to zwyczajny wymóg każdego urzędu kościelnego) ${ }^{16}$, ale bez przyznawania prawa do wynagrodzenia ze strony Kościoła, jak to zostało stwierdzone w ostatniej frazie kan. 230 $\$ 1$. Wydaje się, że prawodawca rozumie, iż takie posługi nie są zajęciem wyłącznym ich tytulariusza, ale mogą być łączone z pracą lub wykonywaniem zawodu. Gdyby mężczyźni ci poświęcili się całkowicie sprawowaniu swojej posługi, mieściłby się w zakresie określonym w kan. $231 \S 2$ i mieliby prawo do odpowiedniego wynagrodzenia oraz zapewnienia ubezpieczenia społecznego i opieki zdrowotnej ${ }^{17}$.

12 A. Jacobs, Les laïcs..., s. 43.

13 Ogólne Wprowadzenie do Mszału Rzymskiego używa nazwy: „Posługa ustanowionych akolitów i lektorów”. Missale Romanum ex decreto sacrocancti Oecumenici Concilii Vaticani II instauratum, auctoritate Pauli Pp. VI promulgatum, Ioannis Paulis Pp. II cura recognitum, editio typica tertia, dei 20 aprilis 2000, nr 98, Città del Vaticano 2002; tekst polski: Kongregacja Kultu Bożego i Dyscypliny Sakramentów, Nowe Ogólne Wprowadzenie do Mszału Rzymskiego, Poznań 2004 (dalej: NOWMR).

14 A. Jacobs, Les laïcs..., s. 44.

15 Por. M. Fernández Conde, La misión profética..., s. 204-205.

16 O posłudze świeckich w Kościele „na stałe” wspomina kan. $231 \S 1$ : „Świeccy, którzy na stałe lub czasowo poświęcają się posłudze Kościoła, obowiązani są zdobyć odpowiednią formację [...]”.

17 M. Fernández Conde, La misión profética..., s. 204; por. A. Jacobs, Les laïcs..., s. 44; por. J. Díaz Moreno, Los laicos..., s. 54-55. 


\section{Normy komplementarne konferencji episkopatów odnośnie do wieku i przymiotów kandydatów do posługi lektoratu i akolitatu}

Kan. $230 \$ 1$ przewiduje, za motu proprio Minsteria quaedam, posługę lektora i akolity przeznaczoną dla mężczyzn laików. Wspomniane ministeria są instytucjami kanoniczno-liturgicznymi, nie święceniami, a ich powierzenie dokonuje się w ramach rytu liturgicznego nakazanego przez stosowny obrzęd. Prawodawca jednak obliguje miejscową konferencję biskupów do wydania norm (dekretu ogólnego) uzupełniających do kan. $230 \$ 1$ odnośnie do wieku i przymiotów kandydatów do tych posług ${ }^{18}$.

Trzeba powiedzieć, że wiek i przymioty mężczyzn świeckich jako kandydatów do posługi lektora i akolity mają istotne znaczenie w kontekście obowiązków i zadań, jakie są związane ze wspomnianymi posługami. Według motu proprio Minsteria quaedam ,lektor jest powołany do właściwej mu funkcji czytania słowa Bożego w zgromadzeniu liturgicznym. Dlatego winien czytać lekcje z Pisma św. (nie zaś Ewangelię) we Mszy i innych świętych czynnościach; w braku psalmisty ma recytować psalm międzylekcyjny; gdzie nie ma diakona lub kantora, powinien zapowiadać intencje modlitwy powszechnej; ma prowadzić śpiew i kierować uczestnictwem Ludu wiernego; przygotowywać wiernych do godnego przyjmowania sakramentów. Może również - jeśli zachodzi potrzeba czuwać nad przygotowaniem innych wiernych, którzy czytają Pismo św. w czynnościach liturgicznych na podstawie tymczasowego zlecenia. Aby zaś bardziej odpowiednio i doskonalej pełnił tę funkcje, winien gorliwie rozważać Pismo św." ${ }^{19}$. „Akolita jest powołany, aby wspierał diakona i posługiwał kapłanowi. Do niego należy troska o służbę ołtarza, pomaganie diakonowi i kapłanowi w sprawowaniu liturgii, zwłaszcza Mszy; ponadto należy do niego, jako do szafarza nadzwyczajnego, udzielanie Komunii św., ilekroć szafarze, których wymienia kan. KPK, są nieobecni lub nie mogą tego uczynić z powodu choroby, podeszłego wieku lub innej funkcji duszpasterskiej, albo ilekroć liczba wiernych przystępujących do świętego Stołu jest tak wielka, że odprawianie Mszy by się przeciągało. W tych samych nadzwyczajnych okolicznościach można mu zlecić wystawienie Najświętszego Sakramentu Eucharystii do publicznej adoracji wiernych, a następnie schowanie, jednak bez udzielenia ludowi błogosławieństwa. Może również - o ile zachodzi potrzeba - zajmować się przygotowaniem innych wiernych, którzy na mocy czasowego upoważnienia pomagają kapłanowi

\footnotetext{
18 Zob. J. Martín de Agar, Estudio comparado de los decretos generales de las conferencias episcopales, Ius Canonicum 1992, t. 32, nr 63, s. 183-184.

MQ, nr 5; por. NOWMR, nr 99.
} 
lub diakonowi w czynnościach liturgicznych, nosząc mszał, krzyż, świece itd. lub wykonując inne podobne funkcje"20.

Według Dyrektorium o pasterskiej posłudze biskupów „w szczególności biskup niech powierza lektorowi, oprócz czytania Słowa Bożego podczas zgromadzenia liturgicznego, zadanie przygotowywania innych wiernych do proklamacji Słowa Bożego, a także pouczania wiernych o godnym uczestniczeniu w obrzędach sakramentalnych i wprowadzania ich, poprzez odpowiednie spotkania, w zrozumienie Pisma Świętego"21, natomiast „zadaniem akolity jest służenie przy ołtarzu oraz wspomaganie diakonów i kapłanów w czynnościach liturgicznych. Jako nadzwyczajny szafarz Eucharystii może rozdawać komunię świętą w przypadkach koniecznych, a ponadto może wystawiać Najświętszy Sakrament do adoracji wiernych bez udzielania błogosławieństwa. Jemu też przypada troska o przygotowanie tych, którzy posługują przy ołtarzu"22. Wyliczone obowiązki, i to wykonywane na stałe (przez całe lata) istotnie wymagają i określonego wieku, i odpowiednich przymiotów.

Biskupi Stanów Zjednoczonych stosując się do przepisu kan. $230 \$ 1$, postanowili, że: „Krajowa Konferencja Biskupów Katolickich, zgodnie z przepisami kanonu $230 \S 1$ niniejszym postanawia, że laik, który ma być na stałe zaangażowany do posługi lektora lub akolity, musi ukończyć dwadzieścia jeden (21) lat. Kandydat musi również posiadać umiejętności niezbędne do skutecznego głoszenia słowa lub służby przy ołtarzu, być w pełni wtajemniczonym członkiem Kościoła katolickiego, być wolnym od wszelkich kar kanonicznych i prowadzić życie, które będzie odpowiadało podjętej służbie”23.

Konferencja Episkopatu Kanady w sprawie posług akolity i lektora stwierdza, jak następuje: „Zgodnie z przepisem kan. $230 \$ 1$ Kanadyjska Konferencja Biskupów Katolickich niniejszym postanawia, że jeśli świeccy, którzy nie są kandydatami do diakonatu lub kapłaństwa, mają być dopuszczeni do posługi lektora i akolity, muszą mieć ukończone 21 lat. Ponadto mają prowadzić prawdziwe życie chrześcijańskie i cieszyć się dojrzałością ludzką; dobrą reputacją, która pozwoli im przyjąć na siebie

20 MQ, nr 6; por. NOWMR, nr 98; zob. J. Dyduch, Posługa lektora i akolity w świetle obowiazujacych przepisów kościelnych, Ruch Biblijny i Liturgiczny 1987, t. 40, nr 2, s. 133-141.

21 AS, nr 113.

22 Tamże.

23 United States Conference of Catholic Bishops, Complementary norms, Canon $230 \$ 1$ (10 July 2000), http://www.usccb.org/beliefs-and-teachings/what-we-believe/canon-law/complementary-norms/ canon-230-1-installed-lay-ministries.cfm [dostęp: 8.05.2020 r.]. Ze względu na ograniczone ramy artykułu zostaną zaprezentowane przepisy tylko niektórych konferencji episkopatu. 
odpowiedzialność za wspólnotę; muszą być zdolni do współpracy z innymi i posiadać kompetencje niezbędne do wykonywania zamierzonej posługi" ${ }^{24}$.

Konferencja Episkopatu Austrii w sprawie kan. $230 \$ 1$ postanowiła: „Minimalny wiek uprawniający do wykonywania obowiązków lektora i akolity w Austrii wynosi 25 lat. Warunkami koniecznymi do wykonania tego zadania są: ludzka dojrzałość, nieskazitelny styl życia i lojalność wobec Kościoła”25. Z kolei Konferencji Episkopatu Indii sformułowała takie postanowienie: „Wymagania stawiane dla kandydatów ubiegających się o nadanie stałej posługi lektora i akolity są następujące: 1. powinni mieć ukończone 21 lat; 2. powinni posiadać wymaganą dojrzałość ludzką, prawdziwą pobożność, właściwe intencje i być akceptowani przez wspólnotę; 3. powinni mieć pragnienie służenia $\mathrm{w}$ duszpasterstwie i być gotowi do służby w diecezji; [...] 5. lektor powinien umieć nie tylko czytać słowo Boże, ale także je objaśniać, bez uszczerbku dla kanonu $767 \$ 1$, akolita powinien nie tylko służyć przy ołtarzu, ale także być animatorem liturgicznym. Obydwaj muszą być prawdziwymi ewangelizatorami i być zdolni do przewodzenia na spotkaniach modlitewnych"26.

W związku z kan. $230 \$ 1$ Konferencja Episkopatu Holandii ogłosiła: „Ustalamy, że mianowanie na stałe do funkcji lektora lub akolity może nastąpić dopiero po ukończeniu 20 roku życia. Najlepiej byłoby, gdyby ta funkcja została powierzona tym, którzy są lub zostali wyznaczeni jako liderzy zarówno kolegium lektorów, jak i akolitów"27.

Konferencja Episkopatu Niemiec podjęła następującą uchwałę odnośnie do kan. $230 \$ 1$ : „Mężczyźni świeccy, którzy zgodnie z kan. $230 \$ 1$ KPK otrzymują nominację do «stałej posługi lektora i akolity», muszą: a) osiągnąć wiek 25 lat, z wyjątkiem osób wymienionych w punkcie II [alumnów seminariów duchownych - J.A.], b) posiadać gruntowną znajomość Pisma Świętego i liturgii, c) posiadać kwalifikacje do wykonywania obowiązków związanych z daną posługą oraz d) charakteryzują się utrwaloną postawą wiary i sprawdzonym sposobem życia"28. Natomiast Konferencja Episkopatu Meksyku zarządziła: „powierzenie na stałe posług lektora

24 Canadian Conference of Catholic Bishops, Complementary norms to the 1983 Code of Canon Law, Ministries of lector and acolyte, can. $230 \$ 1$, Decree nr 24, Ottawa 1996, s. 13.

25 Österreichische Bischofskonferenz, Dekret über die Voraussetzungen für die Beauftragung zum Lektorat und Akolythat, can. $230 \$ 1$, Amtsblatt der Österreichischen Bischofskonferenz 1991, nr 6, cz. 2, nr 1, s. 3.

26 Conference of Catholic Bishops of India, Complementary Legislations to the Code of Canon Law, http://ccbi.in/wp-content/uploads/2015/12/Complementary-Legislations-to-the-Code-of-CanonLaw-1.pdf [dostęp: 26.02.2020].

27 Re gelingen R.K. Kerkgenootschap in Nederland, nr 5. Toepassingsbesluiten bij de Codex Iuris Canonici, Utrecht 1989, s. 4.

28 Deutschen Bischofskonferenz, Partikularnormen und Allgemeine Dekrete der Deutschen Bischofskonferenz, Partikularnorm Nr. 1 der Deutschen Bischofskonferenz zu c. $230 \$ 1$ CIC Lektorat/Akolythat 
i akolity wymaga: świadectwa życia we wspólnocie, wystarczającej wiedzy, przygotowania liturgicznego i duchowego właściwego dla danego miejsca oraz umiejętności pedagogicznych według należytego osądu ordynariusza, wystarczająco długiego czasu na wykonywanie posługi, którą ma otrzymać, niewykonywanie posługi bez należytego upoważnienia poza wyznaczonym miejscem, przyjęcia posługi przez obrzęd z przedstawieniem przez rektora lub kapłana odpowiedzialnego za wspólnotę. Minimalny wiek uprawniający do podjęcia stałej służby lektorskiej i akolickiej wynosi 18 lat, pod warunkiem że kandydat posiada wystarczającą dojrzałość ludzką oraz odpowiednie przygotowanie doktrynalne i duchowe"29.

Konferencja Episkopatu Japonii ustaliła z kolei, że mężczyźni świeccy, którzy mają poprzez obrzęd liturgiczny przyjąć posługi lektora i akolity, muszą mieć skończone 22 lata życia i należeć co najmniej od trzech lat do Kościoła katolickiego ${ }^{30}$. Konferencja Episkopatu Paragwaju uchwaliła, co następuje: „Konferencja Episkopatu Paragwaju ustanawia wiek 25 lat jako minimalny dla otrzymania stałej posługi lektora i akolity. Mężczyźni świeccy, którzy aspirują do tych posług i posiadają wymagany wiek, powinni spełniać następujące warunki: wzorowe życie chrześcijańskie zarówno w wypełnianiu obowiązków osobistych, jak i w rodzinie, społeczeństwie i środowisku kościelnym, doświadczenie duszpasterskie w ramach organizacji, stowarzyszeń i działalności kościelnej”31.

Konferencja Episkopatu Sri Lanki podjęła następująca decyzję: „Mężczyzna świecki może być przyjęty do stałych posług lektora i akolity, zgodnie z kanonem $230 \$ 1$. Poniżej podane są wymagania dotyczące przyjęcia do powyższych posług: minimalny wiek wymagany do otrzymania tych posług będzie wynosił 21 lat skończonych, musi on być wzorowym chrześcijaninem, powinien posiadać właściwą intencję i silną wolę służenia Bogu i pracy dla zbawienia dusz, powinien cieszyć się dobrą opinią we wspólnocie, wiernie stosować się do nauczania Magisterium"32. Konferencja Episkopatu Włoch ustaliła, jak następuje: „zgodnie z kan. 230 $\$ 1$ Kodeksu prawa kanonicznego mogą być przyjmowani na stałe do świeckich

(Persönliche Voraussetzungen für die durch liturgischen Ritus auf Dauer zu übertragenden Dienste des Lektors und des Akolythen), Kirchlichen Amtsblatt 1995, s. 610-611.

29 Conferencia del Episcopado Mexicano, Decreti generali della Conferenza episcopale del 12 ottobre 1985 e dell'11 aprile 1988, riguardanti la legislazione complementare al codice di diritto canonico, Ius Ecclesiae 1989, t. 1, nr 1, s. 374-375.

30 Por. Conferentia Episcoporum Iapaniae, Normae applicativae C.I.C., 20 febbraio 1992, Ius Ecclesiae 1992 , t. 4 , nr 2, s. 775.

31 Conferenza Episcopale del Paraguay, Norme complementari al C.I.C. 12 novembre 1994, Ius Ecclesiae 1998, t. 10, nr 1, s. 397-398.

32 Catholic Bishops' Conference in Sri Lanka, Complementary Legislation to the Code of Canon Law, Ius Ecclesiae 1994, t. 6, nr 1, s. 383-384. 
posług lektora i akolity ci, którzy z reguły mają co najmniej dwadzieścia pięć lat. Podstawowymi cechami wymaganymi od kandydatów, które ordynariusz winien uznać po poświadczeniu przez proboszcza, są: dojrzałość ludzka, dobra opinia we wspólnocie chrześcijańskiej, pobożność, odpowiednie przygotowanie teologiczno-liturgiczne, udowodniona zdolność do zaangażowania duszpasterskiego, dyspozycyjność do służby w diecezji” ${ }^{33}$. Interesujące są następujące normy Konferencji Episkopatu Filipin: „Kandydat musi spełniać następujące wymagania: a) musi być wzorowym katolikiem; h) musi mieć co najmniej dwadzieścia jeden lat; c) musi posiadać odpowiednią umiejętność czytania i pisania" ${ }^{34}$.

Wreszcie Konferencja Episkopatu Polski w Instrukcji w sprawie udzielania postugi lektora $i$ akolity świeckim mężczyznom przypomniała: „Kandydaci do posług lektora i akolity powinni odznaczać się wzorowym życiem moralnym, apostolskim oddaniem, bezinteresownością, szczerą pobożnością i gorliwym życiem sakramentalnym, szczególnym umiłowaniem Pisma świętego i Eucharystii. Winni cieszyć się dobrą opinią i być akceptowani przez wiernych parafii, do której należą i w której będą wypełniać powierzone im zadania. Muszą oni posiadać także odpowiednie przymioty intelektualne, stosowne wykształcenie, wyróżniać się solidnością w pracy oraz umiejętnością współpracy z innymi” ${ }^{35}$. Instrukcja ta, mająca charakter wykonawczy w stosunku do postanowień II Synodu Plenarnego, przywołuje jego postanowienia: „O udzielaniu [posług lektoratu i akolitatu - J.A.] świeckim mężczyznom mówi natomiast II Polski Synod Plenarny. Postanowił on, że »mężczyźni świeccy, którzy ukończyli przynajmniej dwadzieścia pięć lat, cieszą się dobrą opinią, posiadają odpowiednie przymioty i są przygotowani do swych zadań poprzez odpowiednią formację, mogą być przyjęci do posługi stałego akolity. Posługę lektora można udzielać w wieku wcześniejszym «"36.

33 Conferenza Episcopale Italiana, Età e doti dei laici candidati ai ministeri di lettore e di accoliti, can. 230 $\$ 1$, w: Delibere e decreti della Conferenza Episcopale Italiana, Milano 2005, s. 71.

34 Catholic Bishops' Conference of the Philippines, Norms approved for the local implementation of some provisions of the New Code of Canon Law, Ius Ecclesiae 1992, t. 4, nr 1, s. 349.

35 Konferencja Episkopatu Polski, Instrukcja w sprawie udzielania postugi..., nr 11, s. 43. Przywołana instrukcja ma charakter wykonawczy w stosunku do postanowień II Synodu Plenarnego. Przypomina znaczenie tych posług oraz określa zasady formacji kandydatów. Zob. szerzej: Z. Janczewski, Instrukcja Episkopatu Polski w sprawie udzielania posługi lektora i akolity świeckim mężczyznom z 2007 r. jako forma realizacji postanowień Kodeksu Prawa Kanonicznego z 1983 r., Prawo Kanoniczne 2009, t. 52, nr 1-2, s. 139-153.

36 Konferencja Episkopatu Polski, Instrukcja w sprawie udzielania posługi..., nr 2-3, s. 41; II Polski Synod Plenarny (1991-1999), Poznań 2001; Liturgia Kościoła po Soborze Watykańskim II, nr 84. 


\section{Inne przepisy konferencji biskupich w kwestii kandydatów do posługi lektoratu i akolitatu nieobjęte postanowieniem kan. 230 § 1}

Prawodawca kodeksowy zobowiązuje konferencje biskupów odnośnie do kan. 230 $\$ 1$ do wydania norm uzupełniających jedynie w kwestii wieku i przymiotów mężczyzn świeckich jako kandydatów do posługi lektoratu i akolitatu. Wiele konferencji wydało wraz ze wspomnianymi normami jeszcze inne przepisy, które nie są wymaganymi wprost normami komplementarnymi do kan. $230 \$ 1$, ale mają istotne znaczenie dla instytucji lektoratu i akolitatu ${ }^{37}$. Bardzo ważną kwestią jest formacja do tych posług, szczególnie ta początkowa. Mówią o tym następujące przepisy znajdujące się w tytule II, cz. I, ks. IV KPK - kan. $228 \$ 1$ : „Odpowiednio przygotowani świeccy są zdolni, by otrzymać od świętych pasterzy te urzędy kościelne i posługi, które wolno im piastować zgodnie z przepisami prawa” oraz kan. $231 \S 1$ : „Świeccy, którzy na stałe lub czasowo poświęcają się posłudze Kościoła, obowiązani są zdobyć odpowiednią formację potrzebną do właściwego wykonywania swego zadania, by ją spełniali świadomie, umiejętnie i pilnie”. Trzeba zauważyć, że jeśli akolici, lektorzy i inni laicy podejmują się obowiązku stałej posługi w Kościołowi (i go otrzymują), mają nie tylko obowiązek, ale i prawo do uzyskania odpowiedniej formacji, aby móc ten obowiązek wypełnić. Stąd tekst kan. $231 \$ 1$ wydaje się jednak niekompletny w tym sensie, że powinien ustalać, i to dość konkretnie, że hierarchia kościelna jest zobowiązana do stworzenia koniecznych lub dogodnych sposobów, aby można było otrzymać wspomnianą formację $e^{38}$.

Wydaje się, że kan. $230 \$ 1$ powinien zobowiązywać konferencje episkopatu do wydania norm komplementarnych dotyczących także formacji kandydatów do posługi lektoratu i akolitatu. Kan. $231 \$ 1$ mówi ogólnie o formacji do wszystkich posług wykonywanych przez laików w Kościele. Można sądzić, że w stosunku do akolitów i lektorów ustanowionych na stałe jest on niewystarczający. W świetle kan. 231 $\$ 1$ przepisy o wspomnianym kształceniu mogłyby wydawać różne kompetentne autorytety kościelne: biskup diecezjalny, konferencja episkopatu, synod prowincjalny. Wprawdzie autorzy Dyrektorium o pasterskiej posłudze biskupów przypominają, że „biskup nie zaniedba tego, aby lektorom i akolitom umożliwić właściwą formację duchową, teologiczną i liturgiczną, tak by mogli uczestniczyć w życiu sakramentalnym Kościoła coraz bardziej świadomie"39, to jednak przepisy konferencji biskupów, z reguły jako instrukcja lub obszerniejsze dyrektorium ujednoliciłyby

37 Zob. J. Martín de Agar, Estudio comparado..., s. 183-184.

38 J. Díaz Moreno, Los laicos..., s. 54.

39 AS, nr 113. 
formację oraz nadałyby jej wyższą rangę. Byłyby one otwarte na prawodawstwo diecezjalne, które mogłoby je uszczegółowić. Trzeba zauważyć, że KPK zobowiązuje konferencje do ustalenia trzyletniego programu formacji dla kandydatów do stałego diakonatu ${ }^{40}$ oraz do opracowania programu kształcenia kapłańskiego ${ }^{41}$. Ze względu na genezę i „pokrewieństwo” posług lektoratu i akolitatu z obszarem duchownym oraz ich stabilność, normy komplementarne konferencji o formacji laików do wymienionych posług byłyby, jak się wydaje, bardzo pożądane $e^{42}$.

W sprawie formacji do posług lektora i akolity niektóre konferencje stanowią, że kandydaci mają brać „udział w odpowiednich szkoleniach teologicznych i praktycznych zgodnie z przepisami diecezjalnymi” ${ }^{43}$, „powinni przejść odpowiednią

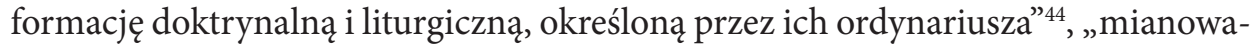
nie kandydatów do diakonatu lub prezbiteratu do posługi lektorskiej i akolity odbywa się w czasie przewidzianym przez diecezjalny regulamin formacyjny dla diakonów i kapłanów, wprowadzony w życie przez biskupa diecezjalnego” ${ }^{45}$, „biskup opracuje w swojej diecezji dyrektorium, którego celem będzie określenie sposobu realizacji dyspozycji udzielonych przez konferencję episkopatu, zwłaszcza w odniesieniu do przygotowania duchowego, biblijnego i liturgicznego świeckich" ${ }^{\prime 4}$, świeccy aspirujący do posługi liturgicznej lektoratu i akolitatu mają „przejść formację"47, mają zrealizować „wystarczające przygotowanie doktrynalne, aby mogli z pożyt-

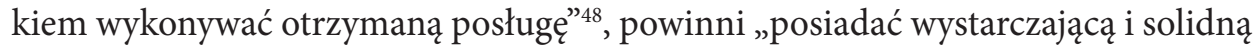
znajomość nauki chrześcijańskiej, a także od pewnego czasu aktywnie uczestniczyć w działalności parafialnej”"49, powinni posiadać „odpowiednie przygotowanie teologiczno-liturgiczne” ${ }^{\text {, }}$, ukończyli „seminarium utworzone w celu właściwego szkolenia i kształcenia lektorów i akolitów” ${ }^{\text {, }}$, „osoby, które pragną przyjąć posługę lektora lub akolity muszą przejść odpowiednią formację. Nie może ona mieć jedynie charakteru kursu przygotowującego do spełniania czynności liturgicznych, lecz

40 Kan. 236.

41 Kan. 242.

42 Tak uczyniła Konferencja Episkopatu Polski, zob. Instrukcję w sprawie udzielania posługi lektora i akolity świeckim mężczyznom.

43 Österreichische Bischofskonferenz, Dekret über die Voraussetzungen..., nr 1, s. 3.

44 Conference of Catholic Bishops of India, Complementary Legislations..., nr 4.

45 Deutschen Bischofskonferenz, Partikularnormen und Allgemeine Dekrete der Deutschen Bischofskonferenz. Partikularnorm Nr. 1..., cz. 2, nr 1, s. 611.

46 Conferencia del Episcopado Mexicano, Decreti generali della Conferenza episcopale..., s. 375.

47 Conferentia Episcoporum Iapaniae, Normae applicativae..., s. 775.

48 Conferenza Episcopale del Paraguay, Norme complementari..., s. 398.

49 Catholic Bishops' Conference in Sri Lanka, Complementary Legislation..., s. 384.

50 Conferenza Episcopale Italiana, Età e doti dei laici candidati..., s. 71.

51 Catholic Bishops' Conference of the Philippines, Norms approved for the local..., s. 349. 
być wprowadzeniem kandydatów w misję, którą mają spełniać w Kościele. Szczegółowy program tej formacji („Ratio formationis”) opracuje Komisja Episkopatu ds. Kultu Bożego i Dyscypliny Sakramentów. Dla osób, które są już po studiach teologicznych lub po pełnej formacji w ruchach kościelnych albo po wieloletniej posłudze i formacji w zespole służby liturgicznej, przygotowanie do posług lektora i akolity może trwać krócej. Opracowane „Ratio formationis” określi minimum, które powinni oni podjąć"52.

Inną kwestią jest udział kompetentnej władzy kościelnej co do przyjmowania kandydatów i wykonywania przez nich posługi. Kodeks nie przyznaje konferencjom biskupim kompetencji w tym zakresie, ale wiele z nich wyraziło swoją opinię. Prawie zawsze wymaga się wezwania lub przyjęcia samego biskupa diecezjalnego albo przełożonego zakonnego (Argentyna, Berlin, Boliwia, Kolumbia, Malta), w innych przypadkach - miejscowego ordynariusza (Szwajcaria) lub kompetentnego ordynariusza (Brazylia, Chile) $)^{53}$.

Niektóre konferencje ustanowiły kontrolę negatywną omawianych posług w tym sensie, że władza kościelna może sprzeciwić się przyjęciu kandydata do posługi lub jej wykonywaniu, a nawet odwołać danej osobie posługę, gdy istnieją uzasadnione powody. Na przykład w Niemczech biskup może, z uzasadnionych powodów, zawiesić wykonywanie posługi, w Portugalii ordynariusz może to zrobić tymczasowo lub ostatecznie, a proboszcz okazjonalnie. Na Filipinach pozwolenie na wykonywanie omawianej posługi musi być odnawiane co roku. W Nigerii przewiduje się rezygnację z posługi z powodu niegodnego życia; w Beninie istnieje nieprawidłowość $\mathrm{w}$ wykonywaniu otrzymanego ministerstwa ${ }^{54}$.

52 Konferencja Episkopatu Polski, Instrukcja w sprawie udzielania posługi..., nr 12, s. 44.

53 J. Martín de Agar, Estudio comparado..., s. 183. Na przykład: „Kandydat na lektora lub akolitę przedstawia biskupowi diecezjalnemu, po uzgodnieniu z własnym proboszczem, dobrowolnie sporządzoną i własnoręcznie podpisaną prośbę" (Konferencja Episkopatu Polski, Instrukcja w sprawie udzielania postugi..., nr 13, s. 44). Kandydat ma być „zaaprobowany przez miejscowego ordynariusza” (Conferentia Episcoporum Iapaniae, Normae applicativae..., s. 775). Kandydaci mogą na stałe otrzymać posługi lektora i akolity „po uzyskaniu rekomendacji ich właściwego proboszcza lub miejscowego ordynariusza, po konsultacji z ich wspólnotą chrześcijańską, Radą Parafialną, jeśli to konieczne" (Kenya Episcopal Conference, Complementary Norms, Ius Ecclesiae 1997, nr 2, s. 827-828).

54 J. Martín de Agar, Estudio comparado..., s. 183-184. Na przykład: „Kandydat do diakonatu lub prezbiteratu, który wycofuje się z przygotowań do święceń, może wykonywać powierzoną mu posługę lektora i/lub akolity tylko wtedy, gdy biskup diecezjalny, który dokonał nominacji, nie odwoła jej, a miejscowy ordynariusz miejsca zamieszkania udzieli wyraźnej zgody" (Deutschen Bischofskonferenz, Partikularnormen und Allgemeine Dekrete der Deutschen Bischofskonferenz, Partikularnorm Nr. 1 ..., cz. 2, nr 2, s. 611). „Lektor i akolita ustanawiani są na stałe. Jednak w szczególnych przypadkach biskup może zabronić im wykonywania ich funkcji: a. Wykonywanie uprawnień właściwych akolicie odnośnie do Eucharystii, a także uprawnień właściwych lektorowi ulega zawieszeniu z chwilą przerwania przez alumnów studiów seminaryjnych z jakiegokolwiek powodu, chyba że biskup diecezjalny 


\section{Zakończenie}

1) Konferencje episkopatów mogą wprowadzić na swoim terytorium posługi lektoratu i akolitatu mężczyzn świeckich na stałe.

2) W przypadku wprowadzenia wymienionych ministeriów konferencje zobowiązane są do wydania norm uzupełniających odnośnie do wieku i przymiotów kandydatów.

3) Wydaje się, że w kwestii określenia wieku oraz przymiotów mężczyzn świeckich jako kandydatów do posługi lektoratu i akolitatu konferencje biskupów powinny ustalić także maksymalny wiek do podjęcia tych posług.

4) Konferencje powinny wydać normy tyczące się przygotowania początkowego do podjęcia wspomnianych posług i formacji stałej, a także postawić wymóg uzyskania zgody żony w przypadku kandydatów żonatych.

5) Pożytecznym byłoby wydanie instrukcji (dyrektorium) w sprawie udzielania i wykonywania posługi lektora i akolity świeckim mężczyznom na stałe.

6) Celowym będzie określenie kto dopuszcza, przyjmuje i odwołuje lektorów i akolitów oraz z jakiego powodu to czyni.

7) Wydaje się, że nie można automatycznie przyjąć normy, według której wykonywanie uprawnień właściwych akolicie odnośnie do Eucharystii, a także uprawnień właściwych lektorowi ulega zawieszeniu z chwilą przerwania przez alumnów studiów seminaryjnych z jakiegokolwiek powodu.

8) Posług lektora i akolity na stałe winno się udzielać mężczyznom niedążącym do święceń w instytutach życia konsekrowanego, stowarzyszeniach życia apostolskiego czy w instytutach świeckich.

\section{Bibliografia}

Aldazábal J., Vocabulario básico de liturgia, Barcelona 2002.

Barr D., Commentary on canon 230, w: New Commentary on the Code of Canon Law, red. J. Beal, New York 2000, s. 298-301.

Blanco M., La mujer en el ordenamiento jurídico canónico, Ius Ecclesiae 1992, t. 4, nr 2.

Díaz Moreno J., Los laicos en el nuevo Código de Derecho Canónico. Temática actual, Revista Española de Derecho Canónico 1989, nr 126.

inaczej postanowi. Podobne postanowienie może podjąć biskup diecezjalny z uzasadnionych przyczyn w odniesieniu do świeckich mężczyzn" (Konferencja Episkopatu Polski, Instrukcja w sprawie udzielania postugi..., nr 17, s. 44-45). 
Dyduch J., Komentarz do kan. 230, w: Komentarz do Kodeksu Prawa Kanonicznego, t. 2, ks. II (1). Lud Boży, red. J. Krukowski i in., Poznań 2005.

Dyduch J., Postuga lektora i akolity w świetle obowiązujących przepisów kościelnych, Ruch Biblijny i Liturgiczny 1987, t. 40, nr 2.

Dyduch J., Udział świeckich w kulcie liturgicznym w świetle Kodeksu prawa kanonicznego, Ruch Biblijny i Liturgiczny 1985, nr 1.

Fernández Conde M., La misión profética de los laicos del Concilio Vaticano II nuestros días. El laico, «signo profético» en los ámbitos de la Iglesia y del mundo, Roma 2001.

Jacobs A., Les laïcs, membres du peuple de Dieu, à travers le Code de droit canonique, Revue Théologique de Louvain 1987, nr 18.

Janczewski Z., Instrukcja Episkopatu Polski w sprawie udzielania postugi lektora i akolity świeckim mężczyznom z 2007 r. jako forma realizacji postanowień Kodeksu Prawa Kanonicznego z 1983 r., Prawo Kanoniczne 2009, nr 1-2.

Martín de Agar J., Estudio comparado de los decretos generales de las conferencias episcopales, Ius Canonicum 1992, nr 63. 
